\title{
Bio-Efficacy of Pseudomonas fluorescens Against the Root-Knot Nematode (Meloidogyne incognita) in Tomato Plant
}

\author{
Siddharth Shankar Sonkar ${ }^{1}$, Jayant Bhatt ${ }^{1}$, Jhumishree Meher ${ }^{2 *}$ and Punam Kashyap ${ }^{1}$ \\ ${ }^{1}$ Department of Plant Pathology, Jawaharlal Nehru Krishi Viswa Vidyalaya, Jabalpur, \\ Madhya Pradesh, India \\ ${ }^{2}$ Department of Mycology and Plant Pathology, Institute of Agricultural Sciences, Banaras \\ Hindu University, Varanasi, Uttar Pradesh, India
}

*Corresponding author

\section{Keywords \\ Bacterial concentration $P$. fluorescens, Biotic- \\ induced resistance, \\ Tomato, Nematode $M$. \\ incognita, Bare root dip, \\ Soil drench \\ Article Info \\ Accepted: \\ 12 October 2018 \\ Available Online: \\ 10 November 2018}

\section{A B S T R A C T}

Pseudomonas fluorescens culture was applied at different dilutions to induce resistance in Tomato (Solanum esculentum L.) against the root-knot nematode, Meloidogyne incognita. The efficacy of this culture, when applied as a soil drench or root dip, was compared with inoculated non-treated plants under greenhouse conditions. P. fluorescens was able to reduce nematode parameters at all dilutions and in both types of application. The dilution $9 \times 10^{8} \mathrm{cfu} / \mathrm{ml}$ was the most effective in reducing nematode reproduction as measured by the number of developmental stages, Plant height $(\mathrm{cm})$, Root length $(\mathrm{cm})$, Fresh and dry weight of Shoot and Root (gm), No. of galls/plant, and No. of egg masses/gall nematode reduction was $28.68 \mathrm{~cm}, 21.83 \mathrm{~cm}, 8.90 \mathrm{gm}, 2.12 \mathrm{gm}, 4.76 \mathrm{gm}, 0.89 \mathrm{gm}, 28.75$ and 38.50 respectively) when treated as a soil drench compared to the untreated control inoculated with $M$. incognita only. This was followed by $P$. fluorescens at a concentration of $6 \mathrm{~g} / \mathrm{kg}$ soil which significantly reduced the same parameters by $40.30 \mathrm{~cm}, 27.15 \mathrm{~cm}, 35.49 \mathrm{gm}$, $7.18 \mathrm{gm}, 0.85 \mathrm{gm}, 0.26 \mathrm{gm}, 17.00$ and 47.75 , respectively compared to control inoculated with $M$. incognita only. Also, plant growth criteria improved in treated plots compared to controls. The activity of three enzymes (peroxidase, polyphenol oxidase and chitinase) increased in treated plants exposed to $9 \times 10^{8} \mathrm{cfu} / \mathrm{ml}$ as bare root dip treatment and $6 \mathrm{~g} / \mathrm{kg}$ soil as soil drenching compared to the inoculated untreated control. P. fluorescens thus induced resistance in tomato against $M$. incognita.

\section{Introduction}

Certain strains of Pseudomonas fluorescens are able to suppress a variety of plant diseases caused by soil-borne plant pathogens, and hence are of considerable agricultural value (Kloepper 1993). Previous studies demonstrated that specific rhizobacteria reduce plant infection by various plant parasitic nematodes (Oostendrop and Sikora, 1990; Muthulakshmi et al., 2010). A pot culture study was conducted by Jonathan and Umamaheswari (2006) to assess the biocontrol potential of endophytic bacteria. A significant reduction in nematode population was observed in the combined treatment of EPB 5 + 31. Munif et al., (2001) reported that the endophytic bacterium Pseudomonas pullida 
Mt-19 was able to reduce $M$. incognita on tomato when applied as a seed treatment and/or soil drench. Siddiqui and Shaukat (2002) reported that two rhizobacteria, Pseudomonas aeruginosa strain IE-6S+ and $P$. fluorescens strain CHA0, used as a bare rootdip treatment or as a soil drench, substantially reduced $M$. javanica juvenile penetration into tomato roots under glasshouse conditions. The chemical, physical and biological factors which in total constitute its habitat. Temperature, soil texture and structure as well as moisture affect motility, penetration and buildup of populations of nematode species. Temperature has been found to be an important environmental factor that influences the ability of root-knot nematodes to penetrate and develop within a host. The optimum temperature for growth and reproduction of $M$. javanica is $25-30{ }^{\circ} \mathrm{C}$, while the optimum temperature for survival of eggs and juveniles in soil is $10-15^{\circ} \mathrm{C}$. Optimum moisture favors population buildup, while too low or too high moisture is detrimental to the survival of nematodes (Tadele, 1998). The degree of crop damage due to root-knot nematodes depends on the population density of nematodes, susceptibility of the crop and environmental conditions, such as fertility, moisture and presence of other pathogenic organisms, which may, in turn, interact with nematodes (Tadele, 1998).

\section{Materials and Methods}

\section{Isolation and purification of nematode culture}

Root-knot nematode infested tomato plants (Plate 1-B) were collected from the fields of nearby vegetable growing villages of Jabalpur and isolation was done as per Baermann's funnel technique modified Cobb's sieving and decanting method (Christie and Perry, 1957). The extraction was carried out at room temperature $\left(25^{\circ} \mathrm{C} \pm 2\right)$ and the second stage juveniles (J2) were collected 24 and $48 \mathrm{~h}$. The extraction was further continued till 72 to $96 \mathrm{~h}$ and juveniles emerged within $96 \mathrm{~h}$ were used for the inoculation after calibrating the population. Two methods were employed to inoculate plant with nematode population i.e., by dispersed inoculation method and Point Inoculation Method as described by Grewal et al., 1974.

\section{Isolation and mass multiplication of bacterial bio-agents}

Pseudomonas fluorescens was also isolated from the soil of Jabalpur by serial dilution technique and was multiplied on sorghum seeds. The seeds were boiled in water for half an hour and excess moisture was drained. The boiled seeds of sorghum were filled in polypropylene bags@ @ 500g seeds / bag and autoclaved at temperature of $121.6{ }^{\circ} \mathrm{C}$ and at $1.05 \mathrm{~kg} / \mathrm{cm}^{2}$ pressure for 20 minutes. After cooling, the bags were inoculated with pure culture of bacteria and incubated at $24^{\circ} \mathrm{C}$ for ten days. When sufficient growth was achieved the load was determined by haemocytometer. After calculating the cfu/ ml $\left(9 \times 10^{8}\right) 400 \mathrm{ml}$ bacterial suspension of Pseudomonas fluorescens were mixed with one $\mathrm{kg}$ of purified talc powder (sterilized). To this $15 \mathrm{~g}$ of calcium carbonate was added to adjust the $\mathrm{pH}$ to neutral.

\section{Efficacy of isolated bacterial bio-agent against root-knot nematode}

\section{Soil treatment}

Talc containing Pseudomonas fluorescens was incorporated in soil @ 2,4 and $6 \mathrm{~g} / \mathrm{kg}$ soil and Carbofuran (@1 $\mathrm{g} / \mathrm{kg}$ ) filled in ten cm earthen pots containing $500 \mathrm{~g}$ sterilized soil. Four replications for each treatment were maintained and inoculated with 1000 freshly hatched surface sterilized second stage juveniles. 


\section{Bare root dip treatment}

Seeds of tomato (Lycopersicon esculentum cv. Pusa Ruby) after surface sterilization in $1 \%$ Sodium hypochlorite solution were washed thoroughly under running tap water and allowed to dry under a laminar flow hood.

These seed were sown and 2 week old seedlings were uprooted and washed in sterilized distilled water to remove soil particles. These seedlings were dipped in suspensions of Pseudomonas fluorescens with $9 \times 10^{8} \mathrm{cfu} / \mathrm{ml}, \quad 9 \times 10^{6} \mathrm{cfu} / \mathrm{ml}$ and $9 \times 10^{4} \mathrm{cfu} / \mathrm{mlfor} 1$ hour.

All the plant protection measures were employed to grow healthy crop. The glass house temperature ranged from 12 to $39{ }^{\circ} \mathrm{C}$ during the course of investigation. After 45 days of inoculation observations on plant height, root length, shoot weight (fresh and dry), Root weight (fresh and dry), number of galls and number of egg masses/gall were recorded.

\section{Results and Discussion}

Efficacy of Pseudomonas fluorescens isolate against root-knot nematode (Meloidogyne incognita) as soil treatment

The data presented in Table 1 indicated that maximum plant height $(43.31 \mathrm{~cm})$ was noted in carbofuran followed by Pseudomonas fluorescens at $6 \mathrm{~g} / \mathrm{kg} \quad(40.30 \mathrm{~cm})$. Pseudomonas fluorescens at 4 and $2 \mathrm{~g} / \mathrm{kg}$ recorded 37.18 and $31.05 \mathrm{~cm}$, uninoculated control reduced $(32.10 \mathrm{~cm})$ plant height. Minimum $(21.83 \mathrm{~cm})$ plant height was recorded in inoculated control. Similar trend was observed with root length. Significantly higher root length $(27.15 \mathrm{~cm})$ was noted in $6 \mathrm{~g} / \mathrm{kg}$ soil and minimum $(17.23 \mathrm{~cm})$ in inoculated control. Carbofuran showed maximum root length $(29.60 \mathrm{~cm})$.
Fresh weight of shoots and roots were also influenced by the higher dose of Pseudomonas fluorescens $(6 \mathrm{~g} / \mathrm{kg})$ which recorded $35.49 \mathrm{~g}$ and $7.18 \mathrm{~g}$ weight respectively. Minimum fresh shoot and root weights (12.42 and 2.44 g) were recorded in inoculated control and maximum (36.89 and $8.31 \mathrm{~g}$ ) shoot and root weight were recorded in Carbofuran.

Significant increase in fresh shoot and root weights were also noted in $4 \mathrm{~g} / \mathrm{kg}$ (29.74 and $5.14 \mathrm{~g})$ and $2 \mathrm{~g} / \mathrm{kg}$ (4.14 and $0.69 \mathrm{~g})$ Pseudomonas fluorescens incorporated pot soils as against inoculated control.

On dry weight basis, maximum shoot and root weights $(0.95$ and $0.36 \mathrm{~g})$ were recorded in Carbofuran and minimum in inoculated control $(0.27$ and $0.10 \mathrm{~g})$.

Significant increase $(0.85$ and $0.26 \mathrm{~g})$ in the weights was noted in Pseudomonas fluorescens $6 \mathrm{~g} / \mathrm{kg}$ soil followed by $4 \mathrm{~g} / \mathrm{kg}(0.76$ and $0.23 \mathrm{~g})$ and $2 \mathrm{~g} / \mathrm{kg}(0.69$ and $0.16 \mathrm{~g})$ Pseudomonas fluorescens incorporated pot soils.

Minimum number of (5.25) galls/plant were recorded in Carbofuran followed by the treatment where Pseudomonas fluorescens incorporated soils@6g/kg (17.00).

Significantly reduced numbers of galls were recorded in $4 \mathrm{~g} / \mathrm{kg}$ (30.50) and $2 \mathrm{~g} / \mathrm{kg}$ (35.25) as against maximum number of (48.75) galls in inoculated control.

Similarly, there was significant decrease (10.25) in number of egg masses/gall in Carbofuran followed by the treatment where Pseudomonas fluorescens was inoculated @ $6 \mathrm{~g} / \mathrm{kg}$ soil (47.75). Significantly less number of egg masses/gall was also recorded in $4 \mathrm{~g} / \mathrm{kg}$ (56.00) and $2 \mathrm{~g} / \mathrm{kg}(70.00)$ as against maximum number of (74.50) egg masses/gall in inoculated control. 
Efficacy of Pseudomonas fluorescens isolate against root knot nematode (Meloidogyne incognita) as bare root dip treatment

The data presented in the Table 2 indicated that maximum plant height $(35.96 \mathrm{~cm})$ was noted in Carbofuran followed by uninoculated control $(35.62 \mathrm{~cm})$. Significantly higher plant height was recorded in Pseudomonas fluorescens $9 \times 10^{8} \mathrm{cfu} / \mathrm{ml}, \quad(34.69 \mathrm{~cm})$.
Pseudomonas fluorescens at $9 \times 10^{6}$, and $9 \times 10^{4}$ $\mathrm{cfu} / \mathrm{ml}$, recorded 32.60 and $31.48 \mathrm{~cm}$ plant height respectively. Minimum plant height $(29.20 \mathrm{~cm})$ was recorded in inoculated control. Similar trend was noted with root length. Significantly higher root length $(29.73 \mathrm{~cm})$ was noted in Pseudomonas fluorescens at $9 \times 10^{8} \mathrm{cfu} / \mathrm{ml}$, and minimum $(26.58 \mathrm{~cm})$ in inoculated control. Carbofuran showed maximum root length $(30.68 \mathrm{~cm})$.
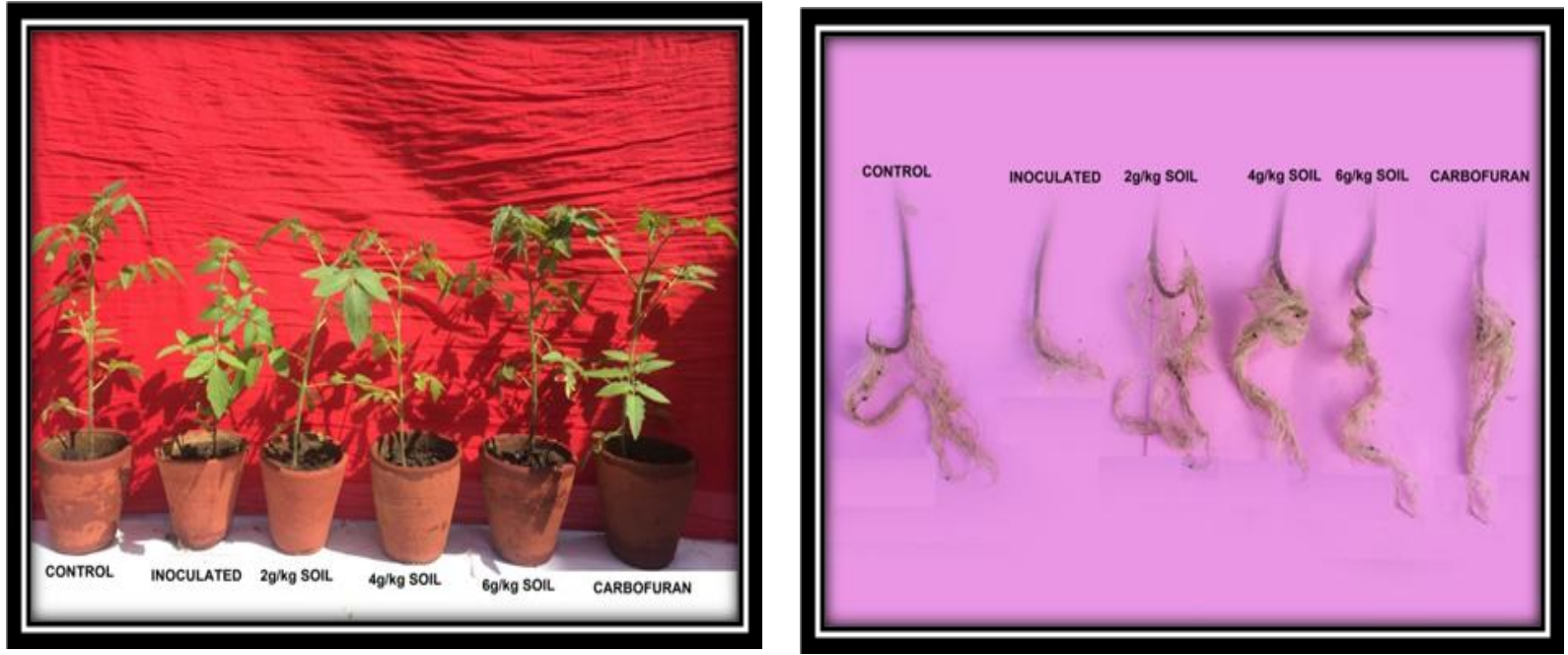

Plate-1

Effect of Pseudomonas fluorescens against root knot nematode (Meloidogyne incognita) as soil treatment in tomato Shoot and Root.


Plate-2

Effect of Pseudomonas fluorescens.against root knot nematode (Meloidogyne incognita) as bare root dip treatment in tomato plant 
Table.1 Efficacy of Pseudomonas fluorescens isolate against root-knot nematode (Meloidogyne incognita) as soil treatment

\begin{tabular}{|c|c|c|c|c|c|c|c|c|c|}
\hline \multirow[t]{2}{*}{ S. No. } & \multirow[t]{2}{*}{ Treatment } & \multirow[t]{2}{*}{$\begin{array}{l}\text { Plant height } \\
(\mathrm{cm})\end{array}$} & \multirow[t]{2}{*}{$\begin{array}{l}\text { Root length } \\
(\mathrm{cm})\end{array}$} & \multicolumn{2}{|c|}{$\begin{array}{l}\text { Fresh weight } \\
\text { (g) }\end{array}$} & \multicolumn{2}{|c|}{ Dry weight (g) } & \multirow[t]{2}{*}{$\begin{array}{l}\text { No. of } \\
\text { galls/plant }\end{array}$} & \multirow[t]{2}{*}{$\begin{array}{l}\text { No. of egg } \\
\text { masses/gall }\end{array}$} \\
\hline & & & & Shoot & Root & Shoot & Root & & \\
\hline 1 & Control (Uninoculated) & $32.10 *$ & 22.90 & 30.23 & 5.23 & 0.57 & 0.13 & 00 & 00 \\
\hline 2 & Control (Inoculated) & 21.83 & 17.23 & 12.42 & 2.44 & 0.27 & 0.10 & $48.75(7.05)^{* *}$ & $74.50(8.69)^{* *}$ \\
\hline 3 & $2 \mathrm{~g} / \mathrm{kg}$ soil & 31.05 & 24.35 & 26.27 & 4.14 & 0.69 & 0.16 & $35.25(6.02)$ & $70.00(8.43)$ \\
\hline 4 & $4 \mathrm{~g} / \mathrm{kg}$ soil & 37.18 & 25.45 & 29.74 & 5.14 & 0.76 & 0.23 & $30.50(5.61)$ & $56.00(7.55)$ \\
\hline 5 & $6 \mathrm{~g} / \mathrm{kg}$ soil & 40.30 & 27.15 & 35.49 & 7.18 & 0.85 & 0.26 & $17.00(4.24)$ & $47.75(6.98)$ \\
\hline \multirow[t]{3}{*}{6} & Carbofuron & 43.31 & 29.60 & 36.89 & 8.31 & 0.95 & 0.36 & $5.25(2.50)$ & $10.25(3.35)$ \\
\hline & S.E(m) \pm & 0.48 & 0.33 & 0.16 & 0.14 & 0.03 & 0.02 & $1.05(1.43)$ & $1.46(1.57)$ \\
\hline & $\mathrm{CD}$ at $5 \%$ & 1.44 & 0.98 & 0.48 & 0.41 & 0.09 & 0.07 & $3.11(2.03)$ & $4.33(2.31)$ \\
\hline
\end{tabular}

* Mean of four repetitions.

** Figures in parentheses are $\sqrt{(n}+1)$ transformed values.

Table.2 Efficacy of Pseudomonas fluorescens isolate against root-knot nematode (Meloidogyne incognita) as bare root dip treatment

\begin{tabular}{|c|c|c|c|c|c|c|c|c|c|}
\hline \multirow{2}{*}{ S. No. } & \multirow[t]{2}{*}{ Treatment } & \multirow{2}{*}{$\begin{array}{l}\text { Plant height } \\
\text { (cm) }\end{array}$} & \multirow{2}{*}{$\begin{array}{l}\text { Root length } \\
(\mathrm{cm})\end{array}$} & \multicolumn{2}{|c|}{ Fresh weight (g) } & \multicolumn{2}{|c|}{ Dry weight (g) } & \multirow{2}{*}{$\begin{array}{l}\text { No. of } \\
\text { galls/plant }\end{array}$} & \multirow{2}{*}{$\begin{array}{l}\text { No. of egg } \\
\text { masses/gall }\end{array}$} \\
\hline & & & & Shoot & Root & Shoot & Root & & \\
\hline 1 & Control (Uninoculated) & $35.62 *$ & 30.18 & 46.19 & 12.49 & 1.07 & 0.42 & 00 & 00 \\
\hline 2 & Control (Inoculated) & 29.20 & 26.58 & 21.36 & 4.98 & 0.53 & 0.16 & $59.75(7.79)^{* *}$ & $73.50(8.63)^{* *}$ \\
\hline 3 & $9 \times 10^{4} \mathrm{cfu} / \mathrm{ml}$ & 31.48 & 27.80 & 28.47 & 5.62 & 0.61 & 0.19 & $46.50(6.89)$ & $64.75(8.12)$ \\
\hline 4 & $9 \times 10^{6} \mathrm{cfu} / \mathrm{ml}$ & 32.60 & 28.63 & 42.08 & 6.92 & 0.83 & 0.22 & $21.25(4.72)$ & $45.00(6.78)$ \\
\hline 5 & $9 \times 10^{8} \mathrm{cfu} / \mathrm{ml}$ & 34.69 & 29.73 & 43.76 & 7.89 & 0.91 & 0.27 & $15.25(4.03)$ & $30.25(5.59)$ \\
\hline \multirow[t]{3}{*}{6} & Carbofuron & 35.96 & 30.68 & 44.55 & 11.74 & 1.04 & 0.35 & $3.50(2.12)$ & $7.50(2.92)$ \\
\hline & $\mathrm{S} . \mathrm{E}(\mathrm{m}) \pm$ & 0.46 & 0.69 & 0.66 & 0.25 & 0.04 & 0.04 & $0.54(1.24)$ & $1.11(1.45)$ \\
\hline & $\mathrm{CD}$ at $5 \%$ & 1.38 & 2.06 & 1.96 & 0.74 & 0.11 & 0.11 & $1.61(1.61)$ & $3.30(2.10)$ \\
\hline
\end{tabular}

* Mean of four repetitions.

** Figures in parentheses are $\sqrt{(n}+1)$ transformed values. 
Fresh weights of shoot and root were also influenced by the higher dose of Pseudomonas fluorescens at $9 \times 10^{8} \mathrm{cfu} / \mathrm{ml}$ which recorded (43.76 and $7.89 \mathrm{~g}$ ) weights respectively. Minimum fresh shoot and root weights (21.36 and $4.98 \mathrm{~g}$ ) were recorded with inoculated control and maximum shoot and root weights (46.19 and $12.49 \mathrm{~g}$ ) were recorded in uninoculated control. Significant increase in fresh shoot and root weights was also noted in Pseudomonas fluorescens at $9 \times 10^{6}(42.08$ and $6.92 \mathrm{~g})$ and $9 \times 10^{4} \mathrm{cfu} / \mathrm{ml}$, $(28.47$ and $5.62 \mathrm{~g})$ root treated plants as against inoculated control.

On dry weight basis, maximum shoot and root weights (1.07 and $0.42 \mathrm{~g}$ ) were recorded in uninoculated control and minimum (0.53 and $0.16 \mathrm{~g})$ in inoculated control. Significant increase $(0.91$ and $0.27 \mathrm{~g})$ in the weight was noted in Pseudomonas fluorescens at 9x $10^{8} \mathrm{cfu} / \mathrm{ml}$ followed by Pseudomonas fluorescens at $9 \times 10^{6}(0.83$ and $0.22 \mathrm{~g})$ and 9x $10^{4} \mathrm{cfu} / \mathrm{ml},(0.61$ and $0.19 \mathrm{~g})$ Pseudomonas fluorescens root treated plants.

Minimum number of (3.50) galls/plant was recorded in carbofuran followed by the treatment where roots were dipped in Pseudomonas fluorescens at $9 \times 10^{8} \mathrm{cfu} / \mathrm{ml}$, (15.25). Significantly reduced numbers of galls were recorded in Pseudomonas fluorescens at $9 \times 10^{6}(21.25)$ and $9 \times 10^{4} \mathrm{cfu} / \mathrm{ml}$, (46.50) as against maximum number of (59.75) galls in inoculated control.

Similarly, there was significant decrease (7.50) in number of egg masses/gall in carbofuran followed by the treatment where roots were dipped in Pseudomonas fluorescens at $9 \times 10^{8} \mathrm{cfu} / \mathrm{ml}, \quad(30.25)$. Significantly less number of egg masses/gall was also recorded in Pseudomonas fluorescens at $9 \times 10^{6}(45.00)$ and $9 \times 10^{4} \mathrm{cfu} / \mathrm{ml}$ (64.75) as against maximum number of (73.50) egg masses/gall in inoculated control.
Effect of bioagents on root-knot nematode and plant growth parameters as soil treatment

Pseudomonas fluorescens favoured all the plant growth parameters and adversely affected nematode reproduction at all its concentrations. Maximum increase in growth parameters and reduction in nematode population was recorded at highest level of $P$. fluorescens ( $6 \mathrm{~g} / \mathrm{kg}$ soil) followed by 4 and 2 $\mathrm{g} / \mathrm{kg}$ soil. Drastic reduction in the numbers of galls/plant and egg masses/gall were recorded in highest level.

The experiments conducted by Akhtar et al., (2005), Hadad et al., (2011), Hamida et al., (2011), Joo et al., (2012) and Akhtar et al., (2012) supported the present findings. Significant suppression of nematode multiplication by Pseudomonas fluorescens was due to its capability of altering root exudates which could alter nematode behavior and suppress nematode population in root system (Oostendrop and Sikroa 1989).

\section{Effect of bioagents on root-knot nematode and plant growth parameters as bare root dip treatment}

Pseudomonas fluorescens also followed the same trend. Highest inoculum level of Pseudomonas fluorescens increased plant growth parameters with nematode suppression. Results of the findings of Siddiqui and Shaukat (2004) and Kaur (2016) on tomato also confirm the present findings.

\section{Acknowledgement}

In presenting this text, I feel highly privileged to the Chairman of my Advisory Committee, Dr. Jayant Bhatt and to all other Professors, Associate Professors and Assistant Professor of the Department of Plant Pathology, JNKVV, Jabalpur for their precious guidance, 
keen interest and inferential criticism during the course of study and preparation of the manuscript.

\section{References}

Akhtar, A., Abbasi, H. and Sharf, R. 2012. Antagonistic effects of Pseudomonas fluorescens and Bacillus subtilis on Meloidogyne incognita infecting Vigna mungo L. International Journal of Plant, animal and Environmental Science. 2: 55-63.

Akhtar, A., Abbasi, H., and Sharf, R. 2005. Antagonistic effects of Pseudomonas fluorescens and Bacillus subtilis on Meloidogyne incognita infecting Vigna mungo L. International Journal of Plant, animal and Environmental Science.2: 55-63.

Christie, JR., and Perry, VG. 1957. Removing nematodes from soil. Proceeding Helminthol Society Washington 18: 106 -108 .

Grewal, J.S., Pal, M., and Kulshrestha. 1974. A new record of wilt of gram caused by Fusarium solani. Current Science 43:pp767.

Hadad, ME., Mustafa, MI., Selim, SM., Tayeb, T.S., Mahgoob, A.E.A., Norhan, H., and Aziz, A. 2011. The nematicidal effect of some bacterial biofertilizers on Meloidogyne incognita in sandy soil Brazilian Journal of Microbiology 42: 105-113.

Hamida, A., Abd El-Moneim, Y., Mahmoud, M.A., Hoda, H., Nagwa, A., Jaime, A., and Asmahan, MS., 2011. Protection of Pseudomonas fluorescens against the root-knot nematode, Meloidogyne incognita; Role of Enzyme-induced Resistance in Eggplant. Pest Technology Global Science books.

Jonathan, EL., Umamaheswari, R., 2006. Biomanagement of nematodes infesting banana bacterial endophytes (Bacillus subtilis). Indian Journal of Nematology 36(2), 6303-6960

Joo, BS., Rejish, VJ., Ahmad, IR, Kim, CB., Park, W., Park, DS., Kim, ES., Kim, SD., Lim, J., and Park, YH. 2012. Bacterial Mixture from Greenhouse Soil as a Biocontrol Agent Against RootKnot Nematode, Meloidogyne incognita, on Oriental Melon J. Microbiol. Biotechnol, 22, 114-117.

Kaur R, Joshi N, Virk JS and Sharma S. 2016. Evaluation of Pseudomonas fluorescens for the management of tomato early blight disease and fruit borer Journal of Environmental Biology ISSN: 23940379.

Kloepper, JW.1993. Plant growth promoting rhizobacteria as biological control agents. In: Meeting FB (Ed) Soil Microbial Ecology, Marcel Dekker, New York, USA, pp 255-274

Munif, A., Hallmann, J., Sikora, RA.2001. Induced systemic resistance of selected endophytic bacteria against Meloidogyne incognita on tomato. Mededelingen-Faculteit

Landbouwkundige en Toegepaste Biologische Wetenschappen (Ghent, Belgium) 66, 663-669

Muthulakshm, I M., Devrajan, K., Jonathan, EI.2010. Biocontrol of root knot nematode, Meloidogyne incognita (Kofoid and White) Chitwood in mulberry (Morus alba L.). Journal of Biopesticides3, 479-482

Oostendorp, M. and Sikora, RA. 1989. Seed treatment with antagonistic rhizobacteria for the suppression of Heteroderaschaehtii early root infection of sugarbeet. Rev. Nematol., 12:77-83.

Oostendrop, M. andSikora, RA.1990. In vitro interrelationships between rhizosphere bacteria and Heteroderaschachtii. Revue de Nematoogie 13, 269-274

Siddiqui, IA. And Shaukat, SS. 2002. Rhizobacteria-mediated induction of 
systemic resistance (ISR) in tomato against Meloidogyne javanica. Journal of Phytopathology150, 469-473

Siddiqui, IA., and Shaukat, SS. 2004.Trichoderma harzianum enhances the production of nematicidal compounds in vitro and improves biocontrol of Meloidogyne javanica by Pseudomonas fluorescens in tomato Letters in Applied Microbiology, 38, 169-175 doi:10.1111/j.1472765X.2003.01481.

\section{How to cite this article:}

Siddharth Shankar Sonkar, Jayant Bhatt, Jhumishree Meher and Punam Kashyap. 2018. BioEfficacy of Pseudomonas fluorescens Against the Root-Knot Nematode (Meloidogyne incognita) in Tomato Plant. Int.J.Curr.Microbiol.App.Sci. 7(11): 1692-1699.

doi: https://doi.org/10.20546/ijcmas.2018.711.193 